\title{
A Methodological Approach for Assessing Soil Salinity Hazard in Irrigated Areas. Case Study: The RUT Irrigation District, Colombia*
}

\author{
Andrés Echeverri-Sánchez** \\ Cristo Facundo Pérez ${ }^{* * *}$ \\ Paola Angulo-Rojas *** \\ Norberto Urrutia-Cobo ${ }^{* * * * *}$
}

Received: 14/07/2015 - Accepted: 26/05/2016

DOI: 10.22395/rium.v15n29a1

\begin{abstract}
A methodology towards assessing soil salinity hazard at irrigated areas of Colombia was developed based on both electrical conductivity and solubility of salts in water. First, irrigated areas were identified; and then, their physicochemical parameters were determined for characterizing electrical conductivity of water $(\mathrm{ECW})$ as well as predicting salt contents in water by employing the Solsariego model. Afterwards, levels of salinity hazard were assessed by matching classes of ECw and solubility of salts in water. Finally, the salinity hazard was mapped for each irrigated zone. As a major conclusion, we consider that the methodological approach based on water quality assessment (ECW, salt contents, and their solubility in the irrigated water) allowed to prioritize hazard level. Hence, we can address activities for managing the soil salinity in the case study.
\end{abstract}

Key words: soil salinisation, risk management, water quality assessment.

* This article is derived from the doctorate thesis "Methodological model to identify of soil salinization risk in soluble phase in areas under irrigation", by the Ph.D. candidate Andrés Fernando Echeverri Sánchez, and directed by Professor Ph.D. Norberto Urrutia Cobo (REGAR research group). The project sponsors were COLCIENCIAS, ASORUT and Universidad del Valle. The research execution period was from June 2013 to December 2015.

** Ph.D. candidate, Universidad del Valle, Cali, Colombia. REGAR research group, College of EIDENAR, Universidad del Valle. Calle 13 No. 100-00, Bld. 344, office 2019, AA 25360 Cali, Colombia. Email: andres.echeverri@correounivalle.edu.co

*** Water Management MSc. Student, UNESCO-IHE, Delft, the Netherlands. Member of the REGAR research group, College of EIDENAR, Universidad del Valle. Calle 13 No. 100-00, Bld. 344, office 2019, AA 25360 Cali, Colombia. Email: perez43@unesco-ihe.org

***** Agricultural engineer, Universidad del Valle, Cali, Colombia. REGAR research group, College of EIDENAR, Universidad del Valle. Calle 13 No. 100-00, Bld. 344, office 2019, AA 25360 Cali, Colombia. Email: paola.angulo@correounivalle.edu.co

***** Full professor REGAR research group, College of EIDENAR, Universidad del Valle. Lider of REGAR research group. Email: norberto.urrutia@correounivalle.edu.co + Corresponding author. 


\title{
Propuesta metodológica para la valoración y zonificación de la amenaza de salinización de suelos en distritos de riego de zonas semiáridas. Caso de estudio de caso: distrito de riego RUT, Valle del Cauca, Colombia
}

\begin{abstract}
Resumen
Se desarrolló una metodología para la evaluación y mapeo de la amenaza de salinización de suelos en distritos de riego de Colombia, con base en la concentración y tipo de sales en el agua de riego. La evaluación inició con la identificación de áreas de riego y la caracterización de sus parámetros fisicoquímicos. Esta caracterización permitió, por un lado, conocer la concentración de sales a través de la CEw, y por otro, estimar los tipos de sales presentes empleando el modelo Sosalriego. Luego, se asignaron niveles de amenaza en cada zona de riego, los cuales fueron espacializados empleando SIG. Finalmente, la aplicación del modelo permitió priorizar y orientar acciones de manejo para cada nivel de peligro identificados en el caso de estudio.
\end{abstract}

Palabras clave: salinización de suelos, gestión del riesgo, evaluación de calidad de agua. 


\section{INTRODUCTION}

Food production and water are inextricably linked. Water has always been the main factor limiting crop production in many regions of the world, where rainfall is insufficient to meet crop demand [1] and relying on a network of several scientific institutions, FAO has packaged a set of tools in this Irrigation and Drainage Paper to better appraise and enhance crop yield response to water. These tools provide the means to sharpen assessment and management capacities required to: compare the result of several water allocations plans: improve soil-moisture control-practices under rainfed conditions; optimize irrigation scheduling (either full, deficit or supplementary. Therefore, irrigation has been crucial for improving crop production in those dry areas. $40 \%$ of global food production comes from the $20 \%$ of irrigated areas [2].

However, in agricultural fields there are three principal problems that may arise due to delivered water quality [3]: a) salinity hazard, causing osmotic pressure rises in the soil solution, and thus, it reduces water availability; b) sodicity hazard, resulting in a breakdown of soil aggregates responsible for good soil structure, which is needed for free water and air movement through the soils; and c) toxicity hazard, that affects some crops due to high concentrations of specific ions such as sodium, chloride, boron, carbonates, and molybdenum [4].

Soil salinisation is inconvenient at farmlands since the total amount of salts in water is such that the salts accumulate in the root zone to the extent that crop yields are adversely affected [4]. That's why the U.S. Salinity Laboratory Staff [5] developed an indirect -and wide spread- method of determining the salt content of irrigation water by measuring its electrical conductivity (EC). The higher the salinity contents in irrigation water, the higher its salinity hazard for the crops - that is if the soil and climatic conditions, and cultural practices remain the same, as they may promote accumulation of soluble salts in the root zone [4].

On the other hand, assessing the hazard is "to predict" the occurrence of the phenomenon based on the study of its generating mechanism, and monitoring the process over time. Likewise, the assessment can be improved by mapping the different levels of threats, which is the major input in the physical and territorial planning [6].

Irrigated areas show the highest salinity process in soil [7-10], thus, a tool is needed for managing the soil salinity hazard due to water quality, especially in flat and dry areas. Besides, with the ever-increasing competition for finite water resources and the steadily rising demand for agricultural commodities, the call to improve the efficiency and productivity of water use for crop production, to ensure future food security and address the uncertainties associated with climate change, has never been more urgent 
[1]and relying on a network of several scientific institutions, FAO has packaged a set of tools in this Irrigation and Drainage Paper to better appraise and enhance crop yield response to water. These tools provide the means to sharpen assessment and management capacities required to: compare the result of several water allocations plans: improve soil-moisture control-practices under rainfed conditions; optimize irrigation scheduling (either full, deficit or supplementary.

Hence, this study aimed to develop a methodology -in the risk management framework-for assessing the soil salinity hazard and its mapping over an irrigation district located in a dry region of Colombia.

\section{MATERIALS AND METHODS}

\subsection{Methodological approach}

The methodological approach assesses and maps the soil salinity hazard originating from the delivered water for irrigating flat-dry regions of Colombia. This threat is a component of risk management theory $(\mathrm{R}=$ Hazard $[\mathrm{H}] \mathrm{x}$ Vulnerability [V]) [11] practitioners and the public. The previous version lu201cTerminology: Basic terms of disaster risk reductionlu201d was published in lu201cLiving with risk: a global review of disaster risk reduction initiativeslu201d in 2004. The following year, the Hyogo Framework for Action 2005-2015 requested the UNISDR to lu201cupdate and widely disseminate international standard terminology related to disaster risk reduction, at least in all official United Nations languages, for use in programme and institutions development, operations, research, training curricula and public information programmeslu201d. The 2009 version is the result of a process of ongoing review by the UNISDR and consultations with a broad range of experts and practitioners in various international venues, regional discussions and national settings. The terms are now defined by a single sentence. The comments paragraph associated with each term is not part of the definition, but is provided to give additional context, qualification and explanation. It should be noted that the terms are not necessarily mutually exclusive, and in some cases may have overlapping meanings. The Terminology has been revised to include words that are central to the contemporary understanding and evolving practice of disaster risk reduction but exclude words that have a common dictionary usage. Also included are a number of emerging new concepts that are not in widespread use but are of growing professional relevance; these terms are marked with a star (*. Vulnerability assessment, relationship between internal and external factors in soil, will not be considered in this paper. The next four guidelines describe the steps that must be followed in order to successfully achieve the methodological approach: 


\subsubsection{Step 1. Delimitation of irrigated areas and location of sampling points}

Each irrigated area must be defined according to both water source and water quality. Thereby, key spots as catchment, agricultural runoff and sewage dumping points must be identified over the irrigation-network scheme of the irrigation district, which contains main, secondary and tertiary hydraulic distribution. Once these zones are defined, three sampling points must be selected at least -at the beginning, middle, and end- over the main canal of each irrigated area.

\subsubsection{Step 2 . Water quality characterization}

Major parameters such as electrical conductivity (ECw), $\mathrm{pH}$, cations $\left(\mathrm{Ca}^{2+}, \mathrm{Mg}^{2+}, \mathrm{Na}^{+}\right.$, $\left.\mathrm{K}^{+}\right)$, anions $\left(\mathrm{HCO}_{3}^{-}\right.$or $\mathrm{CO}_{3}{ }^{-}, \mathrm{Cl}, \mathrm{SO}_{4}{ }^{-}$and $\left.\mathrm{NO}_{3}^{-}\right)$must be determined for each sampling point, following standard procedures from the American Public Health Association [12]. The sampling campaign must consider changes in weather (e.g. raining and dry season). Thus, the recommended minimum numbers per year are two. However, we should keep in mind that more sampling campaigns per season result in better understanding of such threat over time.

\subsubsection{Step 3. Salinity hazard assessment}

Cations and anions should feed in Solsariego model, which is a procedure to predict salinity and sodicity levels of soil, assessing the irrigation water quality. The computed quality indexes are the amount of required amendment and the leaching fraction values [13]. However, Solsariego only predicts salt contents in the water samples (e.g. Table 6).

The qualitative assessment of salinity hazard (very high [ $\mathrm{vH}]$, high $[\mathrm{H}]$, medium $[\mathrm{M}]$, low $[\mathrm{L}]$, very low $[\mathrm{VL}])$ may be obtained from matching classes of $\mathrm{ECW}$ and solubility of salts in water (Table 1). ECw column shows four groups [5]. On the other hand, the solubility columns illustrate the salt concentration values in three ranges.

Table 1. Matrix for assessing the salinity hazard

\begin{tabular}{|c|c|c|c|}
\hline \multirow{2}{*}{$E C w d S m^{-1}$} & \multicolumn{3}{|c|}{ Solubility of salts in water $\left(\right.$ mmolc $\left.^{-1}\right)$} \\
\cline { 2 - 4 } & $>5,000$ & $5,000-1,000$ & $<1,000$ \\
\hline $0-0.25$ & $\mathrm{~L}$ & $\mathrm{~L}$ & $\mathrm{VL}$ \\
\hline $0.25-0.7$ & $\mathrm{M}$ & $\mathrm{M}$ & $\mathrm{L}$ \\
\hline $0.7-3.0$ & $\mathrm{H}$ & $\mathrm{M}$ & $\mathrm{M}$ \\
\hline$>3.0$ & $\mathrm{VH}$ & $\mathrm{H}$ & $\mathrm{H}$ \\
\hline
\end{tabular}

Source: authors 


\subsubsection{Step 4. Hazard mapping}

Each sampling point holds an influence area, which should be drawn on the irrigation scheme using CAD software, and then converted into a shapefile or feature-class file (vector data). Next, a database should be complied by adding features as location of measuring point, water quality, and qualitative assessment in each polygon. As a result, soil salinity hazard due to water quality may be mapped using the Geographic information system (GIS) tool.

\subsection{Case Study: The RuT Irrigation District}

The study was carried out in the influence area of the Roldanillo-Unión-Toro (RUT) Irrigation District located north of the Valle del Cauca Department, in southwest Colombia. The RUT Irrigation District lies on the flat zone (approx. 10,200 ha) of RUT watershed, and it limits to the north with the Cauca river-Toro Municipality-, east with the left bank of the Cauca river, south with the Cauca river -Roldanillo Municipality-, and west side with the right hillside of the western range mountain of Colombia (Figure 1). Altitude varies between 915 and 980 m.a.s.l. Relieve is slightly sloped (3-7\%). The average annual rainfall is $1,074 \mathrm{~mm}$ and average annual ETo is $1,510 \mathrm{~mm}$. The predominant soil order is alluvial clay, and predominant taxonomic orders are inceptisols, vertisols and mollisols. Natural drainage ranges between slow and moderate, given the heavy texture of the soils [14].

In general terms, the irrigation system is a flood protection and irrigation/drainage scheme. The long and narrow bowl-shaped area is surrounded by a protection dike that runs along the east border of the Cauca River and a flood interceptor canal on the west side. A main drain divides the area almost in half, running through the lowest elevations [15-16].

The main source of water is the Cauca River, whose water has to be pumped up to the main irrigation canal, passing by secondary and tertiary canals towards farms. The flood interceptor canal also acts as an irrigation canal for the water users who use small centrifugal pumps to serve their individual needs. Likewise, there is a network of drainage canals interconnected to the main drain, whose water flows from south to north across the Irrigation District and discharges into the Cauca River.

Despite the fact that The RUT Irrigation District is one of the most important irrigation systems in Colombia, since it holds excellent characteristics (climate, soils, water, and strategic geographical location) for developing agriculture [16]; nowadays, the district shows a growing crisis due to a combination of administrative, technical and environmental factors. For instance, the spoilt state of physical infrastructure, change in cropping pattern (sugarcane monoculture), and inexistent irrigation and 


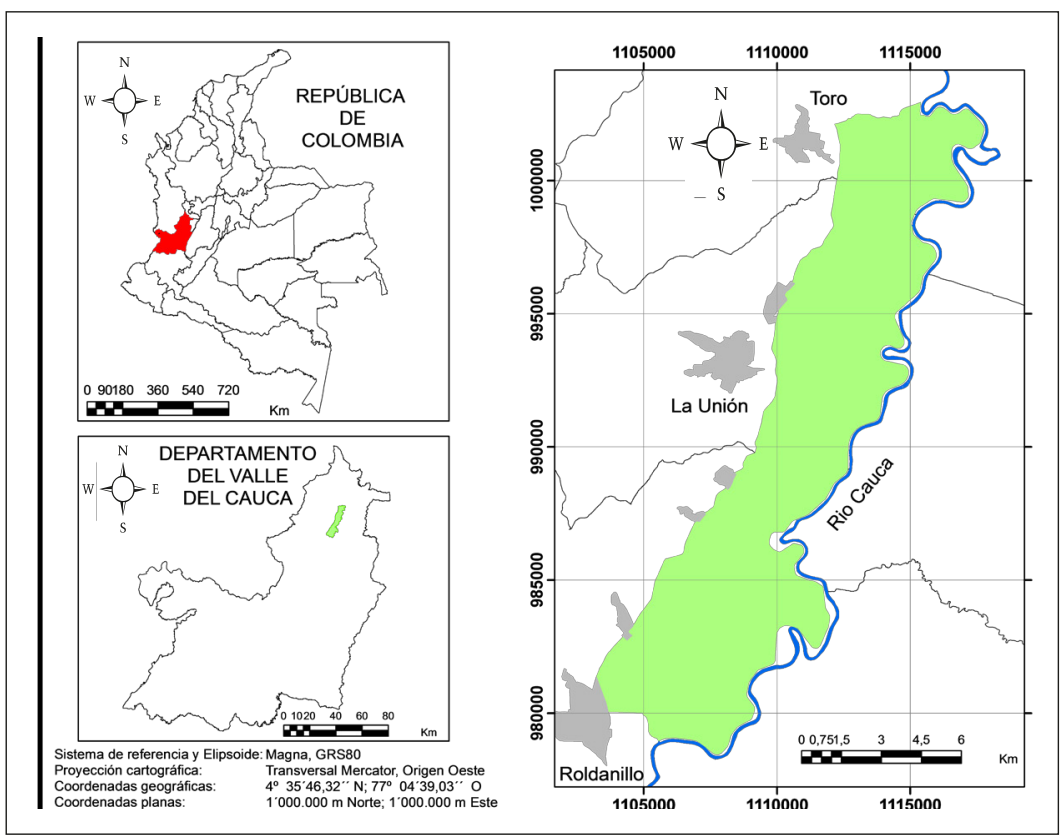

Figure 1. Location of study area

Source: authors

cropping scheduling. We also highlight the inefficiencies in water management, such as the irrigation with water coming from the main drain, which contains a mixture of drainage water plus fertilizer and pesticides, and the interceptor canal is polluted with domestic wastewater from surrounding municipalities.

\subsubsection{Step 1. Location of sampling points and their influence areas}

Several workshops and fieldwork were held along with stakeholders in order to identify key irrigated zones. After that, three zones were arranged to evaluate water quality (Figure 2). Table 2 illustrates general features of each zone.

Table 2. Irrigation zones characteristics

\begin{tabular}{|c|l|}
\hline Zone & \multicolumn{1}{c|}{ Features } \\
\hline I & $\begin{array}{l}\text { Water withdrawal from the Cauca river carried through the main irrigation canal and canal } \\
\text { 1.0. There is not wastewater discharge from nearby villages. }\end{array}$ \\
\hline II & $\begin{array}{l}\text { The interceptor canal conveys water from the Cauca river and also receives wastewater from } \\
\text { nearby villages and municipality treatment plants. }\end{array}$ \\
\hline III & $\begin{array}{l}\text { Irrigation water is supplied by the main drain and the interceptor canal. At this point, north } \\
\text { side, the interceptor canal transports wastewater from La Unión and previous municipalities. }\end{array}$ \\
\hline
\end{tabular}




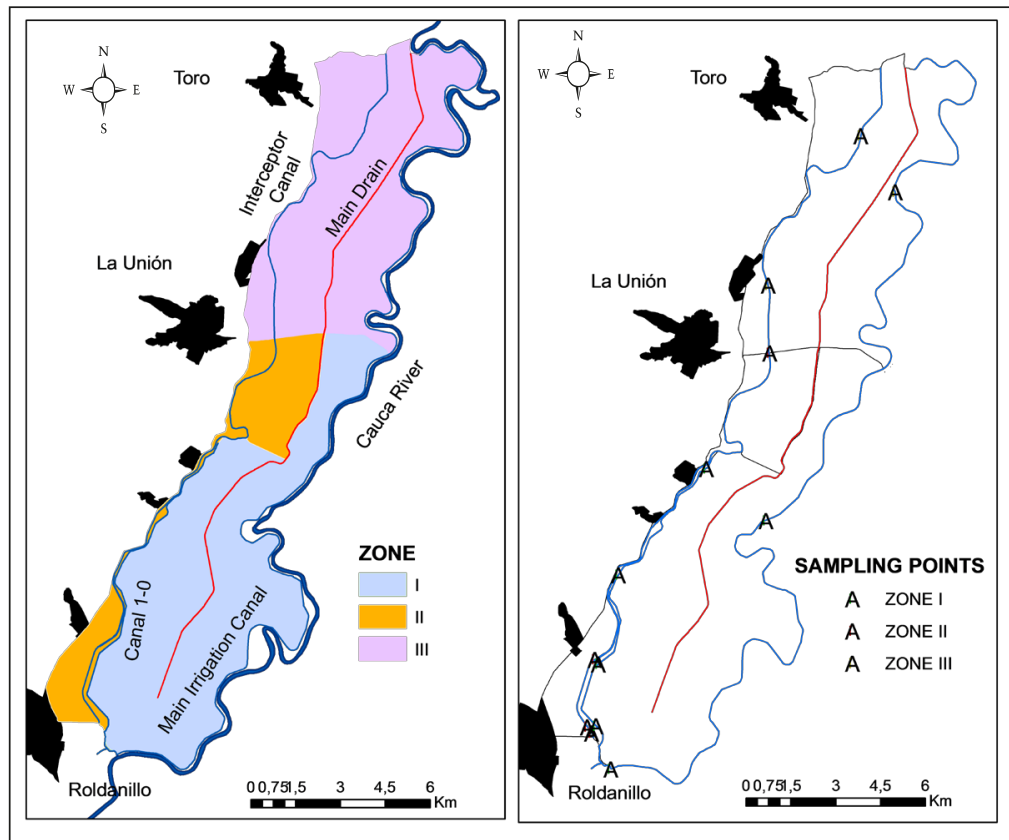

Figure 2. Irrigation zone distribution in the RUT irrigation district Source: authors

\subsubsection{Step 2 . Water quality characterization}

A grab-sample technique with two successive repetitions of sampling was taken between 8:00 and 16:00 hours (matching with the irrigation schedule, from 6:00 to 18:00) for each of the 13 selected sampling points. Three-sampling campaigns were held (September 2013, January 2014 and July 2014), corresponding to dry season in the region.

Statistical Analysis: Two statistical models for water data analysis were employed for testing differences among each irrigated zone (I, II, III) over time (Sep. 2013, Jan. 2014, Jul. 2014) and for comparing means of the irrigation zones (I, II, III).

One-way ANOVA was performed when the independence, normality (ShapiroWilk test) and homogeneity of the variances (Levene test) were verified. Otherwise, nonparametric tests (Kruskal-Wallis) were used in the analysis. Post hoc tests were performed, Tukey-b for ANOVA and pairwise comparison for nonparametric test. IBM $^{\circledR}$ SPSS $^{\circledR}$ Statistics 20 software was used in the analytical process.

\subsubsection{Steps 3 \& 4. Hazard assessment of salinization and hazard mapping}

Salinity hazard was classified using table 1, as proposed in step 3 of the methodological approach. Then, hazard classes were mapped along The RUT Irrigation District 
-following step 4 of the methodological approach- by employing Autocad 10 and ArcGIS 10.3.

\section{RESULTS AND DISCUSSIONS}

\subsection{Water quality characterization (Step 2)}

As shown in table 3 , concentration values meet Colombian standards ( $\mathrm{pH}$ 6.5-9.0; ECw $1 \mathrm{dS} \mathrm{m}^{-1}$; Ca $60 \mathrm{mg} \mathrm{l}^{-1}$; $\mathrm{Mg} 36 \mathrm{mg} \mathrm{l}^{-1}$; total alkalinity as $\mathrm{CaCO}_{3} 200 \mathrm{mg} \mathrm{l}^{-1} ; \mathrm{Cl}_{2} 250 \mathrm{mg} \mathrm{l}^{-1}$; $\mathrm{SO}_{4} 250 \mathrm{mg} \mathrm{l}^{-1}$ ) present in resolution 2115 of 2007 from the Health and Environmental Ministries of Colombia, for drinking purpose as well as permissible limits (ECw 0.7 dS m ${ }^{-1}$, Na $69 \mathrm{mg} \mathrm{l}^{-1}, 78 \mathrm{mg} \mathrm{l}^{-1}$ ) of the Food and Agriculture Organization of the United Nations (FAO) guidelines for agricultural-water quality [3]. However, comparing them to a previous surface-water assessment study in the RUT Irrigation District [17], there exists a pronounced tendency toward increasing ion concentrations, which point out a forthcoming salinization process in the region.

Table 3. Water quality in The RUT Irrigation District

\begin{tabular}{|c|c|c|c|c|c|c|c|c|c|c|}
\hline \multirow{2}{*}{ Date } & \multirow{2}{*}{ Zone } & \multirow{2}{*}{$p H$} & \multirow{2}{*}{$E C_{w} d S m^{-1}$} & $\mathrm{Ca}$ & $M g$ & $\mathrm{Na}$ & $K$ & $\mathrm{HCO}_{3}$ & $\mathrm{Cl}$ & $\mathrm{SO}_{4}$ \\
\hline & & & & \multicolumn{7}{|c|}{$m g l^{-1}$} \\
\hline \multirow{3}{*}{ Sep. 2013} & I & 7.2 & 0.15 & 10.3 & 6.0 & 7.6 & 2.2 & 57.2 & 7.6 & 16.0 \\
\hline & II & 7.2 & 0.40 & 27.2 & 17.7 & 22.8 & 5.3 & 198.1 & 22.9 & 23.8 \\
\hline & III & 7.3 & 0.50 & 22.3 & 34.5 & 30.0 & 5.2 & 201.7 & 16.6 & 39.2 \\
\hline \multirow{3}{*}{ Jan. 2014} & I & 6.5 & 0.09 & 15.1 & 3.4 & 6.8 & 1.6 & 31.7 & 3.8 & 12.3 \\
\hline & II & 7.0 & 0.20 & 21.0 & 4.3 & 17.2 & 3.4 & 55.1 & 10.2 & 14.2 \\
\hline & III & 7.1 & 0.34 & 39.0 & 6.4 & 27.1 & 2.8 & 111.5 & 13.1 & 27.7 \\
\hline \multirow{3}{*}{ Jul 2014} & I & 6.5 & 0.14 & 9.2 & 5.6 & 9.8 & 0.2 & 38.8 & 9.4 & 17.4 \\
\hline & II & 6.4 & 0.20 & 12.9 & 6.9 & 15.0 & 2.0 & 55.9 & 11.3 & 21.6 \\
\hline & III & 7.0 & 0.35 & 17.3 & 15.9 & 21.5 & 0.6 & 120.5 & 13.2 & 30.8 \\
\hline
\end{tabular}

Source: authors

Table 4 shows that excepting $\mathrm{pH}$, most of the parameters present differences over time in zone I. Zone II showed differences only in $\mathrm{pH}, \mathrm{Mg}$ and $\mathrm{HCO}_{3}$ values. Zone III had changes only in $\mathrm{Mg}$ concentrations over time. On the other hand, comparing irrigation zones at each sampling campaign, statistical differences were found in ECw, $\mathrm{Ca}, \mathrm{Mg}, \mathrm{Na}$ and $\mathrm{HCO}_{3}$ (Table 5), whereas, $\mathrm{Cl}$ evidenced variances in two sampling periods, $\mathrm{pH}$ and $\mathrm{K}$ in only one. No significant difference among ZI, ZII and ZIII was found for $\mathrm{SO}_{4}$. In the meantime, post-hoc tests indicate a strong difference between $\mathrm{ZI}$ and ZII in most of the parameters tested. 
At last, as expected, there are differences amongst ZI, ZII, and ZIII and these are constant over time. The irrigation zone arrangement took into account water features throughout the rut Irrigation District and sampling campaigns were held in dry season.

Table 4. Differences among each irrigation zone over time

\begin{tabular}{|c|c|c|c|c|c|c|c|c|c|c|}
\hline $\begin{array}{c}\text { Statistical } \\
\text { Analysis }\end{array}$ & Zone & $p H$ & $E C w$ & $\mathrm{Ca}$ & $M g$ & $\mathrm{Na}$ & $K$ & $\mathrm{HCO}_{3}$ & $\mathrm{Cl}$ & $\mathrm{SO}_{4}$ \\
\hline \multirow{3}{*}{$\begin{array}{l}\text { p-values } \\
\text { anova }\end{array}$} & I & 0.093 & 0.000 & 0.001 & 0.003 & 0.022 & 0.002 & 0.000 & 0.001 & 0.018 \\
\hline & II & 0.020 & 0.077 & 0.088 & 0.009 & 0.794 & 0.231 & 0.030 & 0.144 & 0.298 \\
\hline & III & 0.550 & 0.361 & 0.075 & 0.027 & 0.482 & 0.067 & 0.097 & 0.705 & 0.804 \\
\hline \multirow{3}{*}{$\begin{array}{c}\text { Pairwise } \\
\text { comparison } \\
\text { Tukey-b }\end{array}$} & I & & $(2)(1-3)$ & $(2)(1-3)$ & (2)(1-3) & $(1-2)(1-3)$ & $(1-2)(2-3)$ & (1) $(2-3)$ & \multirow{3}{*}{\multicolumn{2}{|c|}{$(1-2)(1-3)(1-2)(1-3)$}} \\
\hline & II & $(1-2)(3)$ & & & $(1-3)(2-3)$ & & & $(1-3)(2-3)$ & & \\
\hline & III & & & & $(1-3)(2-3)$ & & & & & \\
\hline
\end{tabular}

Significant level p= 0.05 for both cases. 1 (Sep. 2013), 2 (Jan. 2014), 3 (Jul. 2014).

Source: authors

Table 5. Comparison among irrigation zones

\begin{tabular}{|c|c|c|c|c|c|c|c|c|c|c|}
\hline $\begin{array}{l}\text { Statistical } \\
\text { Analysis }\end{array}$ & Date & $p H$ & $E C w$ & $\mathrm{Ca}$ & $M g$ & $\mathrm{Na}$ & $K$ & $\mathrm{HCO}_{3}$ & $\mathrm{Cl}$ & $\mathrm{SO}_{4}$ \\
\hline \multirow{3}{*}{$\begin{array}{c}\text { p-values } \\
\text { anova }\end{array}$} & Sep. 2013 & 0.655 & 0.010 & 0.017 & 0.000 & 0.010 & 0.024 & 0.013 & 0.011 & 0.659 \\
\hline & Jan. 2014 & 0.014 & 0.007 & 0.001 & 0.038 & 0.060 & 0.073 & 0.032 & 0.008 & 0.058 \\
\hline & Jul. 2014 & 0.607 & 0.005 & 0.024 & 0.005 & 0.000 & 0.333 & 0.006 & 0.095 & 0.357 \\
\hline \multirow{3}{*}{$\begin{array}{l}\text { Pairwise } \\
\text { comparison } \\
\text { Tukey-b }\end{array}$} & Sep. 2013 & \multirow{3}{*}{$\begin{array}{l}\text { (I)(II, } \\
\text { III) }\end{array}$} & $\begin{array}{l}(\mathrm{I})(\mathrm{II}, \\
\mathrm{III})\end{array}$ & $\begin{array}{l}(\mathrm{I}, \mathrm{III})(\mathrm{II}, \\
\text { III) }\end{array}$ & $\begin{array}{l}\text { (I)(II) } \\
\text { (III) }\end{array}$ & \multicolumn{5}{|c|}{$\begin{array}{l}(\mathrm{I}, \mathrm{II})(\mathrm{II},(\mathrm{I}, \mathrm{III})(\mathrm{II},(\mathrm{I}, \mathrm{III})(\mathrm{II},(\mathrm{I}, \mathrm{III})(\mathrm{II}, \\
\begin{array}{llll}\mathrm{III}) & \mathrm{III}) & \mathrm{III}) & \mathrm{III})\end{array}\end{array}$} \\
\hline & Jan. 2014 & & $\begin{array}{l}(\mathrm{I}, \mathrm{II})(\mathrm{II}, \\
\mathrm{III})\end{array}$ & $\begin{array}{c}\text { (I, II) } \\
\text { (III) }\end{array}$ & \multicolumn{3}{|c|}{$\begin{array}{l}(\mathrm{I}, \mathrm{II})(\mathrm{II},(\mathrm{I}, \mathrm{II})(\mathrm{II}, \\
\mathrm{III})\end{array}$} & \multicolumn{3}{|c|}{$\begin{array}{lc}(\mathrm{I}, \mathrm{II})(\mathrm{II}, & (\mathrm{I}, \mathrm{II})(\mathrm{II}, \\
\mathrm{III}) & \mathrm{III})\end{array}$} \\
\hline & Jul. 2014 & & $\begin{array}{c}\text { (I, II)(II, } \\
\text { III) }\end{array}$ & $\begin{array}{c}\text { (I, II)(II, } \\
\text { III) }\end{array}$ & $\begin{array}{c}\text { (I, II) } \\
\text { (III) }\end{array}$ & $\begin{array}{c}\text { (I)(II) } \\
\text { (III) }\end{array}$ & & $\begin{array}{c}\text { (I, II)(I } \\
\text { III) }\end{array}$ & & \\
\hline
\end{tabular}

Significant level p= 0.05 for both cases. I (zone I), II (zone II), III (zone III).

Source: authors

\subsection{Salinization hazard assessment (Step 3)}

In general terms, water composition presents salt contents as follows: $\mathrm{Ca}\left(\mathrm{HCO}_{3}\right)_{2}$ (low solubility), $\mathrm{Mg}\left(\mathrm{HCO}_{3}\right)_{2}$ (very low), $\mathrm{NaCl}$ (high) and $\mathrm{MgSO}_{4}$ (medium) (Table 6). 
Table 6. SOLSARIEGO prediction of salt contents in water

\begin{tabular}{|c|c|c|c|c|c|c|c|c|c|c|c|}
\hline & & \multicolumn{3}{|c|}{ Solubility $<1,000$} & \multicolumn{3}{|c|}{ Solubility $1,000-5,000$} & \multicolumn{4}{|c|}{ Solubility $>5,000$} \\
\hline Zone & Date & $\begin{array}{c}\mathrm{Mg} \\
\left(\mathrm{HCO}_{3}\right)_{2} \\
(\%)\end{array}$ & $\begin{array}{c}\mathrm{CaSO}_{4} \\
(\%)\end{array}$ & $\begin{array}{c}\mathrm{K}_{2} \mathrm{SO}_{4} \\
(\%)\end{array}$ & $\begin{array}{c}\mathrm{Ca}\left(\mathrm{HCO}_{3}\right)_{2} \\
(\%)\end{array}$ & $\begin{array}{c}\mathrm{Na}- \\
\mathrm{HCO}_{3} \\
(\%)\end{array}$ & $\mathrm{KCl}(\%)$ & $\begin{array}{c}\mathrm{MgSO}_{4} \\
(\%)\end{array}$ & $\begin{array}{c}\mathrm{Na}_{2} \mathrm{SO}_{4} \\
(\%)\end{array}$ & $\begin{array}{c}\mathrm{NaCl} \\
(\%)\end{array}$ & $\begin{array}{c}\mathrm{MgCl}_{2} \\
(\%)\end{array}$ \\
\hline I & Sep. 2013 & 30.5 & 0.0 & 4.0 & 36.7 & 0.0 & 0.0 & 5.1 & 8.3 & 15.4 & 0.0 \\
\hline I & Jan. 2014 & 0.0 & 26.6 & 2.5 & 58.7 & 0.0 & 2.0 & 0.0 & 0.0 & 10.2 & 0.0 \\
\hline I & Jul 2014 & 14.2 & 0.0 & 0.5 & 36.2 & 0.0 & 0.0 & 22.4 & 5.9 & 20.9 & 0.0 \\
\hline II & Sep. 2013 & 37.0 & 0.0 & 3.4 & 34.4 & 11.0 & 0.0 & 0.0 & 0.0 & 14.2 & 0.0 \\
\hline II & Jan. 2014 & 0.0 & 9.8 & 5.9 & 60.8 & 0.0 & 0.0 & 41 & 0.0 & 19.3 & 0.0 \\
\hline II & Jul 2014 & 16.4 & 0.0 & 3.0 & 38.0 & 0.0 & 0.0 & 17.2 & 6.5 & 18.9 & 0.0 \\
\hline III & Sep. 2013 & 47.8 & 0.0 & 2.9 & 24.3 & 0.0 & 0.0 & 14.1 & 0.8 & 10.2 & 0.0 \\
\hline III & Jan. 2014 & 0.0 & 4.3 & 2.6 & 67.2 & 0.0 & 0.0 & 14.3 & 0.0 & 6.6 & 5.0 \\
\hline III & Jul 2014 & 37.1 & 0.0 & 0.5 & 28.9 & 0.0 & 0.0 & 6.7 & 14.3 & 12.5 & 0.0 \\
\hline
\end{tabular}

The zone 1 classed low salinity hazard for all sampling campaigns (Table 7). Meanwhile zone 2 fell into medium class at Sep. 2013 campaign and low at Jan. 2014 and Jul. 2014 Zone III classified low at Sep. 2013 and medium at the other two campaigns. According to these results, and as found in statistical analysis, there is a pronounced difference between ZI and ZIII.

Table 7. Salinity hazard classification

\begin{tabular}{|c|c|c|c|c|c|c|c|}
\hline \multirow{2}{*}{ Zone } & \multirow{2}{*}{ Date } & \multirow{2}{*}{$E C_{w}$} & \multicolumn{3}{|c|}{$\begin{array}{l}\text { Solubility of salts in ranked water } \\
\qquad\left(\mathrm{mmol}_{c} \mathrm{~L}^{-1}\right)\end{array}$} & \multirow{2}{*}{ Total (\%) } & \multirow{2}{*}{ Class } \\
\hline & & & $\begin{array}{c}0-1,000 \\
(\%)\end{array}$ & $\begin{array}{c}1,000- \\
5,000(\%)\end{array}$ & $\begin{array}{l}>5,000 \\
(\%)\end{array}$ & & \\
\hline \multirow{3}{*}{ I } & Sep. 2013 & 0.148 & 30.5 & 54.1 & 15.4 & 100 & $\mathrm{~L}$ \\
\hline & Jan. 2014 & 0.090 & 26.6 & 63.2 & 10.2 & 100 & $\mathrm{~L}$ \\
\hline & Jul. 2014 & 0.140 & 14.2 & 65.0 & 20.9 & 100 & $\mathrm{~L}$ \\
\hline \multirow{3}{*}{ II } & Sep. 2013 & 0.400 & 37.0 & 48.8 & 14.2 & 100 & M \\
\hline & Jan. 2014 & 0.204 & 9.8 & 70.8 & 19.3 & 100 & $\mathrm{~L}$ \\
\hline & Jul. 2014 & 0.199 & 16.4 & 64.7 & 18.9 & 100 & $\mathrm{~L}$ \\
\hline \multirow{3}{*}{ III } & Sep. 2013 & 0.495 & 47.8 & 42.0 & 10.2 & 100 & $\mathrm{~L}$ \\
\hline & Jan. 2014 & 0.340 & 4.3 & 84.1 & 11.6 & 100 & $\mathrm{M}$ \\
\hline & Jul. 2014 & 0.345 & 37.1 & 50.4 & 12.5 & 100 & M \\
\hline
\end{tabular}


ZII keeps similar ranks of solubility among sampling campaigns (Table 7), but $\mathrm{EC}_{\mathrm{w}}$ value for Sep. 2013 fell in a different class (Table 1), thus its classification was higher than the other seasons. On the contrary, salt contents in ZIII classed low (Table 1) in Sep. 2013 due to low value for salt solubility.

\subsection{Hazard mapping (Step 4)}

Given the hazard mapping for each tested season (Figure 3), here is a pattern of greater qualification (medium) on the northern side of the RUT Irrigation District. As described in table 1, the interceptor canal transports wastewater that originates in Roldanillo, La Unión and Toro Municipalities; whereas the main drain conveys water with high concentrations of fertilizer and pesticides.

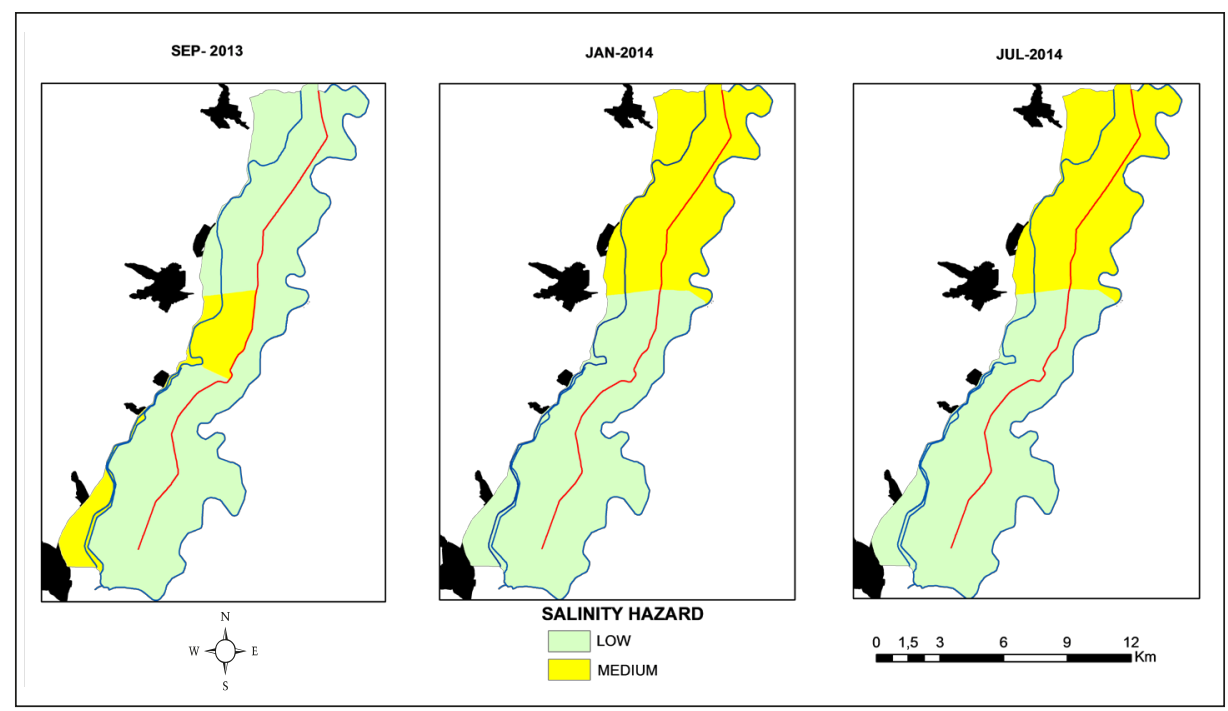

Figure 3. Soil salinity hazard due to irrigation water quality Source: authors

In general terms, proposals such as setting a water treatment process, employing another water resource or canceling the irrigation activity might control the soil salinity hazard (ECw and salt contents) in the RUT Irrigation District. Nonetheless, these solutions are unfeasible due to their high operational cost. Thus, we would like to propose alternatives that may be more suitable for Colombian circumstances. The southern zone of the RUT Irrigation District (I and II) shows low salinity hazard, therefore, main activities must focus on improving efficiencies of the irrigation methods and hydraulic distribution, as well as adopting a tight irrigation schedule based on climate, soil moisture and crop water needs. In the case of the northern area of the Irrigation District (Zone III), apart from the above-mentioned activities, irrigation with water from 
main drain must be prevented and water resources as the Cauca River or shallow/deep wells should be developed. In addition, growing crops with low water requirements or medium tolerant crops may be suitable solutions. However, these proposals are partial options as we are facing only hazard. Considerations for addressing the vulnerability component must be considered as well.

\section{CONCLUSIONS}

We consider the methodological approach based on water quality assessment $\left(\mathrm{EC}_{\mathrm{w}}\right.$ and prediction of salt contents in water) is a helpful tool for decision makers in irrigation districts in flat and dry regions of Colombia, since they can address resource investments in a specific way, according to the hazard levels and their locations. In other words, this proposal may be extended to irrigation districts with similar characteristics. However, the results are partial since it is important to consider, not only one component of the risk management, but also the vulnerability, and its intrinsic and extrinsic factors related to irrigation water quality (hazard).

Concerning the study case, through the methodological approach two hazard zones, low and medium level, were identified, as well as their sources. In the first zone, lowlevel hazard is caused by the type of salts; whereas in the second zone, medium-level hazard is due to the combination effect from ECw and the type of salts. Thus, activities for facing hazard would be specific for each area.

\section{ACKNOWLEDGMENTS}

Authors would like to thank COLCIENCIAS (Calls PhD. and young researcher-CV 7232012), ASORUT, and REGAR research groups from Universidad del Valle for their support and funding of the research study.

\section{REFERENCES}

[1] P. Steduto, T. C. Hsiao, E. Fereres \& D. Raes, Crop yield response to water. FAo Irrigation and Drainage Paper No. 66, Rome: FAO, 2012, p. 501. Available: http://www.fao.org/nr/water/ docs/IrrigationDrainage66.pdf

[2] FAO, "Water and food security. Irrigation and Under Nourishment, 1998-2000", in Water at a Glance, Food and Agriculture Organization of the United Nations, 2007. [Online]. Available: http://www.fao.org/nr/water/art/2007/glance/security3.html

[3] R. S. Ayers \& D. W. Westcot, Water quality for agriculture. FAo Irrigation and Drainage Paper No. 29. Rev. 1, Rome: FAO, 1985, p. 97. Available: http://www.fao.org/docrep/003/T0234E/ T0234E00.htm

[4] I. P. Abrol, J. S. Yadav \& F. I. Massoud, Salt-Affected Soils and their Management, FAO Soils Bulletin 39, Rome: FAO, 1988. Available: http://www.fao.org/docrep/x5871e/x5871e00.htm 
[5] USSL-Staff, "Diagnosis and Improvement of Saline and Alkaline Soils," Soil Science Society of America Journal, vol. 18, no. 3, p. 348, 1954.

[6] O. Cardona, "Evaluación de la amenaza, la vulnerabilidad y el riesgo. Elementos para el ordenamiento y la planeación del desarrollo", in Los desastres no son naturales, A. Maskrey, Ed. Bogota: Tercer Mundo, 1993, pp. 45-65.

[7] A. Akramkhanov, C. Martius, S. J. Park \& J. M. H. Hendrickx, "Environmental factors of spatial distribution of soil salinity on flat irrigated terrain", Geoderma, vol. 163, no. 1-2, pp. 55-62, Jun. 2011.

[8] L. C. Stringer, "Global land and soil degradation: challenges to soil," in $1^{\text {st }}$ Global Soil Week: Soils for Life, Berlin, Germany, Nov. 18-22, 2012. Available: http://globalsoilweek.org/wpcontent/uploads/2014/12/GSW-2012_IssuePaper_Global-Land-and-Soil-Degradation.pdf

[9] D. Zhou, Z. Lin, L. Liu \& D. Zimmermann, “Assessing secondary soil salinization risk based on the PSR sustainability framework," J. Environ. Manage., vol. 128, pp. 642-654, 2013.

[10] F. Bouksila, A. Bahri, R. Berndtsson, M. Persson, J. Rozema \& S. E. a. T. M. Van der Zee, "Assessment of soil salinization risks under irrigation with brackish water in semiarid Tunisia," Environ. Exp. Bot., vol. 92, pp. 176-185, Aug. 2013.

[11] United Nations International Strategy for Disaster Reduction, UNISDR, 2009 UNISDR Terminology on Disaster Risk Reduction, Geneva, Switzerland: United Nations International Strategy for Disaster Reduction, UNISDR, May 2009, p. 30. Available: http://www.unisdr.org/ files/7817_UNISDRTerminologyEnglish.pdf

[12] American Public Health Association, APHA, Standard Methods for the Examination of Water and Wastewater, $20^{\text {th }}$ ed., vol. 20. Washington, DC: Amer Public Health Assn, 1999. Available: https://www.mwa.co.th/download/file_upload/SMWW_10900end.pdf

[13] R. Villafañe, "Sosalriego: un procedimiento para diagnosticar los riesgos de sodificación y salinización del suelo con el agua de riego (nota técnica)," Bioagro, vol. 23, no. 1, pp. 57-64, 2011.

[14] Instituto Geográfico Agustín Codazzi,IGAC \& Corporación Autónoma Regional del Valle del Cauca, CvC, Levantamiento de suelos y zonificación de tierras del departamento de Valle del Cauca, Tomo 1, Bogotá, D. C.: Instituto Geográfico Agustín Codazzi, 2004.

[15] M. F. Otero, "Optimization of water management in the RUT irrigation district, Colombia," MSc thesis, UNESCO-IHE,Delft, The Netherlands, 2002.

[16] N. Urrutia Cobo, "Sustainable management after irrigation system transfer: experiences in Colombia - the RUT irrigation district”. Doctor's thesis, UNESCO-IHE,Delft, The Netherlands, 2006.

[17] Corporación Autónoma Regional del Valle del Cauca, CVC, "Diagnóstico del problema de salinidad y drenaje del distrito de riego RuT," Cali, Colombia: CVC,1986. 